\title{
Correlations between acute phase proteins and the body condition score
}

\author{
Mária Vargová ${ }^{1}$, Rudolf Hromada $^{1}$, Katarína Veszelits Laktičová ${ }^{1}$, Terézia Pošiváková ${ }^{1}$, \\ Juraj Benculák ${ }^{1}$, Gabriel Kováč ${ }^{2}$ \\ University of Veterinary Medicine and Pharmacy, \\ ${ }^{1}$ Department of the Environment, Veterinary Legislation and Economy, \\ ${ }^{2}$ Clinic of Ruminants, Košice, Slovak Republic \\ Received November 11, 2016 \\ Accepted October 17, 2017
}

\begin{abstract}
The objective of this study was to evaluate the dynamics of the body condition score, acute phase proteins (serum amyloid A and haptoglobin) and their relationships in dairy cows of the Slovak Pied Cattle from 3 weeks before parturition to 9 weeks after parturition. Significant differences were found in the means of serum amyloid A $(P<0.01)$. Haptoglobin concentrations increased from $172.0 \pm 0.05 \mu \mathrm{g} / \mathrm{ml}$ to $173.0 \pm 0.13 \mu \mathrm{g} / \mathrm{ml}$ at week 3 and week 1 before the parturition, respectively. The highest value of haptoglobin was recorded in cows 3 week post partum. Cows during the early postparturient period had significantly higher serum amyloid A concentrations compared to cows in the prepartal period $(P<0.01)$. Significantly higher body condition score values were observed in dry cows (from $4.42 \pm 0.20$ to $4.25 \pm 0.15$ points) than in cows after parturition (from $3.90 \pm 0.12$ to $3.25 \pm 0.08$ points) $(P<0.001)$. In the assessment of correlations between the selected acute phase proteins significant positive correlation was found $(\mathrm{r}=0.213$, $P<0.05$ ). Moreover, negative correlations were found between the body condition score and acute phase proteins. Our results show a strong relationship between the decrease of the body condition score and the increase of acute phase proteins in dairy cows around parturition which indicates the process of a certain form of non-specific inflammation at loss of body fat.
\end{abstract}

Body status, serum amyloid A, haptoglobin, prepartal period, postpartal period

The time around parturition (periparturient period) is the most important and difficult period for high-yielding dairy cows, which is characterized by a high incidence of metabolic, infectious, and reproductive disorders (Kelton et al. 1998). It spans from 3 weeks ante partum to 3 weeks post partum, and is defined as the change from a gestational non-lactating state to a non-gestational lactating state (Contreras and Sordillo 2011).

Metabolic and hormonal changes associated with the acceleration of milk yield during the transition period may directly or indirectly compromise the immune system, including the initiation of the production of acute phase proteins (APPs), and increase susceptibility to metabolic and infectious diseases (Vargova et al. 2015). The varied reactions of the host to infection, inflammation, or trauma are collectively known as the acute phase response (APR) and encompass a wide range of pathophysiological responses such as pyrexia, leukocytosis, hormone alterations, and muscle protein depletion combining to minimize tissue damage while enhancing the repair process (Sachin et al. 2011). Acute phase proteins (APPs) manifest various activities by which they contribute to destruction of germs and reduction of tissue damage, helping its regeneration (Pyörälä 2000). The acute phase response is mediated by cytokines acting as messengers between the local site of injury and the hepatocytes synthesizing the APPs (Gabay and Kushner 1999). Positive APPs - serum amyloid A (SAA) and haptoglobin (Hp) are produced during the APR associated with anorexia and changed metabolism (Petersen and Nielsen 2003). Acute phase proteins are sensitive innate immune molecules; they are useful for early detection

Address for correspondence:

MVDr. Mária Vargová, PhD.

Department of the Environment, Veterinary Legislation and Economy

University of Veterinary Medicine and Pharmacy

E-mail: mariavargova24@gmail.com

Komenského 73, 04181 Košice, Slovak Republic

http://actavet.vfu.cz/ 
of inflammation in bovines and seem to be better discriminators than routine haematological indices (Manimaran et al. 2016). The measurement of acute phase proteins may also be useful in defining the objective health status of an animal or a herd.

As the cow transitions from the less demanding non-lactating dry stage to the highly stressful lactation stage, energy and mineral deficiencies occur resulting in metabolic disorders and reduction of the body condition score (BCS) (Markusfeld et al. 1997). The BCS provides an easy and reliable method to evaluate the nutritional status, efficacy of the feeding system and to assess changes in energy reserves (Sheldon et al. 2006). Overconditioned cows will mobilize more adipose tissue before and after calving than will cows with a lower BCS (Kokkonen et al. 2005).

The objective of this study was to examine the concentrations of serum amyloid-A and haptoglobin; changes of the BCS as well as the relationships between the SAA, Hp and $\mathrm{BCS}$ in dairy cattle during ante partum and post partum periods.

\section{Materials and Methods}

Selected acute phase proteins (haptoglobin and serum amyloid A) and the body condition score were evaluated in dairy cows (aged 3-5 years) of the Slovak Pied Cattle. The cows were classified into six different groups based on similar calving date (according to certain phases of ante partum (a.p.) and post partum (p.p.). The animals $(n=21)$ were divided individually into six groups in which the same cows were used more times:

- Group 1 (G 1) - dairy cows 3 weeks before parturition

(3 wk a.p.)

$(\mathrm{n}=15)$

- Group 2 (G 2) - dairy cows 1 week before parturition

(1 wk a.p.)

(1 wk p.p.)

$(\mathrm{n}=15)$

- Group 3 (G 3) - dairy cows 1 week after parturition

(3 wk p.p.)

$(\mathrm{n}=15)$

- Group 4 (G 4) - dairy cows 3 weeks after parturition

(6 wk p.p.)

- Group 5 (G 5) - dairy cows 6 weeks after parturition

(9 wk p.p.)

$(\mathrm{n}=15)$

$(\mathrm{n}=15)$

$(\mathrm{n}=15)$

The mean production age was 2.5 lactations. The milk yield during the previous lactation was $6668.5 \mathrm{~kg}$ of milk during a 305-day lactation. The animals were fed a total mixed ration (TMR) twice daily, nutrient composition of the TMR varied with the stage of pregnancy and lactation. The dairy cows had free access to drinking water.

Before sample collection, the animals were clinically examined by standard clinical examination procedures (Kováč et al. 2001). The blood samples were collected by direct puncture of vena jugularis. Blood serum was analyzed for selected acute phase proteins. The determinations of Hp and SAA were performed by the method of enzyme linked immunosorbent assay (ELISA) using ELISA kits (Tridelta Development, Ltd., Wicklow, Ireland) in microplates. The BCS was evaluated using a 5-point scale and backfat thickness (BFT) measurements were obtained using a $3.5 \mathrm{MHz}$ linear transducer.

Assessment of the BCS and BFT was done according to Staufenbiel (1997). The examination site was located in the sacral region between the caudal one-quarter and one-fifth connection line going from the dorsal part of the tuber ischiadicum (pins) to the tuber coxae (hooks). This site corresponds to the area between the end of the crista sacralis and the end of the os sacrum (i.e., beginning of the first vertebrae coccygea). Results for BCS are presented as mean BCS and as digression from the physiological values at examined periods. Animals were scored for body condition on the day of their blood collection. The physiological range of the BCS for the Slovak Pied Cattle is 3.25 to 3.75 (dry period), 3.25 to 3.75 (puerperium) and 2.50 to 3.00 (the first 100 days of lactation) (Strapák et al. 2004). The evaluation of the obtained results was performed by the assessment of the mean values (x), the medians, and the standard error (S.E.) in each monitored group of dairy cows. The significance of differences in mean values of $\mathrm{Hp}$ and SAA in relation to the monitored periods was evaluated by non-parametric one way analysis of variance (ANOVA). The significance of differences in mean values of Hp and SAA in relation to the monitored periods was evaluated by Kruskal-Wallis test. The significance of differences in mean of $\mathrm{Hp}$ and SAA between the groups was evaluated by Dunn's Multiple Comparisons Test.

The significance of differences in the mean values of BCS in relation to the monitored periods was evaluated by parametric one way analysis of variance. The significance of differences in mean values of BCS between the groups were evaluated by Tukey's Multiple Comparisons Test. The correlations between monitored variables were evaluated at the same time. Statistical analyses were done using the programme GraphPad Prism 3.0 software.

\section{Results}

Concentrations of Hp and SAA ante partum and post partum are presented in Table 1. Body condition scoring results are summarised in Table 2. Correlations between Hp, SAA and BCS are shown in Table 3. 
Table 1. Concentrations of $\mathrm{Hp}$ and SAA in blood serum during the evaluated period $(\mathrm{x} \pm \mathrm{SE})$.

\begin{tabular}{|c|c|c|c|c|c|c|c|c|}
\hline & & G 1 & G 2 & G 3 & G 4 & G 5 & G 6 & $P$ \\
\hline Hp & $\mathrm{m}$ & 172.0 & 173.0 & 192.0 & 474.0 & 188.0 & 107.0 & ns \\
\hline$\mu \mathrm{g} / \mathrm{ml}$ & S.E. & 0.05 & 0.13 & 0.33 & 0.08 & 0.13 & 0.13 & \\
\hline SAA & $\mathrm{m}$ & $21.07^{\mathrm{a}}$ & 39.01 & $74.05^{\mathrm{a}}$ & 46.10 & 47.32 & 35.33 & $<0.01$ \\
\hline$\mu \mathrm{g} / \mathrm{ml}$ & S.E. & 6.97 & 4.66 & 9.64 & 10.57 & 10.96 & 7.01 & \\
\hline
\end{tabular}

The same superscripts in lines mean significance of differences in mean values between the groups: $P<0.01-\mathrm{a}$ SAA - serum amyloid A; Hp - haptoglobin; $\mathrm{m}$ - median; S.E. - standard error of mean; G 1-G 6 - Group 1- Group 6

The concentrations of haptoglobin ante partum increased from $172.0 \pm 0.05 \mu \mathrm{g} / \mathrm{ml}$ (Group 1) to $173.0 \pm 0.13 \mu \mathrm{g} / \mathrm{ml}$ (Group 2). During the postparturient period, Hp was found to be gradually decreasing from $192.0 \pm 0.33 \mu \mathrm{g} / \mathrm{ml}$ (Group 3) to $107.0 \pm 0.13 \mu \mathrm{g} / \mathrm{ml}$ (Group 6) with the highest mean value in cows 3 weeks post partum (Group 4), however, the difference was non-significant.

Compared to the cows 1 week after parturition (Group 3), significantly lower mean values of SAA $(P<0.01)$ were determined in the cows 3 weeks before parturition (Group 1). The SAA concentration increased before parturition; the highest value was recorded in the early postparturient period $(74.05 \pm 9.64 \mu \mathrm{g} / \mathrm{ml})$. The differences of means of serum amyloid A during the monitored period were significant $(P<0.01)$.

Table 2. Mean values of the body condition score in the monitored period $(x \pm S E)$.

\begin{tabular}{|c|c|c|c|c|c|c|c|c|}
\hline BCS & & G 1 & G 2 & G 3 & G 4 & G 5 & G 6 & $P$ \\
\hline & $\mathrm{x}$ & $4.4^{2 \mathrm{AB}} \mathrm{C}$ & $4.2^{5 \mathrm{aD}} \mathrm{E}$ & $3.9^{0 \alpha} \beta$ & $3.4^{8 \mathrm{~A} a}$ & $3.3^{5 \mathrm{BD}} \alpha$ & $3.2^{5 \mathrm{CE}} \beta$ & $<0.001$ \\
\hline & S.E. & 0.20 & 0.15 & 0.12 & 0.13 & 0.10 & 0.08 & \\
\hline
\end{tabular}

The same superscripts in lines mean significance of differences in mean values between the groups:

$P<0.05-\alpha, \beta ; P<0.01-\mathrm{a} ; P<0.001-\mathrm{A}, \mathrm{B}, \mathrm{C}, \mathrm{D}, \mathrm{E}$

BCS - body condition score; $\mathrm{x}$ - mean; S.E. - standard error of the mean; G 1-G 6 - Group 1-Group 6

Table 2 shows an opposed tendency: the mean BCS 3 weeks before parturition were above the physiological values (4.42 \pm 0.20 points). During the postparturient period, levels of BCS were found to be significantly $(P<0.001)$ decreasing from $3.90 \pm 0.12$ to $3.25 \pm 0.08$ points. The mean BCS in dairy cows 3 weeks ante partum were significantly

Table 3. The correlations between selected acute phase proteins and BCS.

\begin{tabular}{lccc}
\hline & Hp & SAA & BCS \\
\hline Hp & & $0.213^{*}$ & $-0.219^{*}$ \\
SAA & $0.213^{*}$ & & -0.201 \\
BCS & $-0.219^{*}$ & -0.201 & \\
\hline
\end{tabular}

Significance of correlations: * $-P<0.05$

SAA - serum amyloid A; Hp - haptoglobin; BCS - body condition score higher than in cows 3, 6, 9 weeks post partum $(P<0.001)$.

In our study, $\mathrm{Hp}$ and SAA were significantly positively correlated during the evaluated period $(\mathrm{r}=0.213, P<0.05)$ (Table 3). Negative correlations were found between $\mathrm{Hp}$ and BCS, and between SAA and BCS $(\mathrm{r}=-0.219, P<0.05$ and $r=-0.201$, respectively).

\section{Discussion}

The acute phase response is a non-specific and complex reaction of an organism, triggered by different stimuli including injury, trauma, infection, stress, inflammation, as well as neoplasia (Cray et al. 2009). The most important metabolic changes include the highly increased or decreased production of a large family of proteins from the liver, the 
acute phase proteins (Murata et al. 2004). Diagnostically, the most important acute phase proteins in ruminants are haptoglobin and serum amyloid A (Eckersall and Bell 2010). Practical uses and advantages of acute phase protein assays have been described in a large number of scientific reports published in the last few years. It has been described that milk $\mathrm{Hp}$ and SAA accurately reflect the degree of inflammation in cows with mastitis (Kováč et al. 2007). On the other hand, in practice it is very useful to control incidence of mastitis through concentration of a specific APP - milk amyloid A (Kováč et al. 2011).

According to Gymnich et al. (2003) haptoglobin concentrations undergo significant changes around parturition, with the highest values in cows one day post partum. Uchida et al. (1993) evaluated the Hp concentration in cows in the periparturient period and observed significantly higher values around parturition than before and after parturition. Similarly, Kováč et al. (2009) reported an increase of the two main acute phase proteins, $\mathrm{Hp}$ and SAA, in cows after parturition. Our results comply with these findings, as the highest concentration of $\mathrm{Hp}$ and SAA was recorded in cows after parturition.

According to the results presented by Chan et al. (2010), the SAA concentrations in healthy cows reach their highest values within three days after the delivery. Alsemgeest et al. (1993) reported that in cows 24, 48, 72 and $96 \mathrm{~h}$ after delivery, mean SAA concentrations were significantly increased; the highest concentration of SAA was reached $48 \mathrm{~h}$ after calving. This is supported also by our observations, significantly higher SAA concentrations were recorded in cows 3 weeks after calving than before parturition and during the postparturient period.

The body condition score of dairy cows indicates nutritional quality, milk yield, reproductive performance, animal well-being and overall farm profitability in a dairy herd. Body condition scoring is widely used to evaluate the nutritional status in cattle and several scoring charts exist (Edmonson et al. 1989). The body condition score targets of 3-3.5 at calving and a maximum loss of 0.5 points over the entire lactation period have been suggested (Mulligan et al. 2006). The physiological range of BCS for Slovak Pied Cattle is 3.25 to 3.75 (dry period), 3.25 to 3.75 (puerperium) and 2.50 to 3.0 (the first 100 days of lactation) (Strapák et al. 2004). In our experiment, a significant decrease of BCS from $4.42 \pm 0.20$ to $4.25 \pm 0.15$ points during the ante partum period and from $3.90 \pm 0.12$ to $3.25 \pm 0.08$ points during the post partum period was recorded. According to the body condition score results, the cows in this study were overweight (4.42 \pm 0.20 points).

Our study showed a negative correlation between the concentrations of both measured acute phase proteins and the body condition score as well as a positive correlation between the concentrations of SAA and Hp in dairy cows during the monitored period. These results indicate that a decrease in BCS in cows before and after parturition can affect the pattern of secretion of acute phase proteins in dairy cows. The physiological processes taking place around the time of parturition may also be responsible for higher concentrations of acute phase proteins in blood serum. According to the results presented by Montagner (2013), higher BCS loss is associated to increased secretion of $\mathrm{Hp}$, which can be associated to increased risk of disease development. On the other hand, the periparturient period is characterized by a sudden increase in energy requirements imposed by the onset of lactation and by negative energy balance (NEB) (Leroy et al. 2008). An important adaptation to the aforementioned NEB during the periparturient period is the mobilization of fat from body stores and a decreased BCS. Animals may react to these disturbances in their homeostasis and changes in metabolism with a set of physiological changes, including changes in the concentration of some plasma proteins, especially acute phase proteins. The above mentioned data show that there are potential benefits to using acute phase proteins and BCS for the assessment of dairy cow health and productivity. Production of APPs is very close to lipidomics (lipid science). Considerably more information is needed to fully understand how modulation of lipid metabolism during the transition period can affect dairycows' 
health (mainly in overconditioned cows with higher BCS). Degradation of adipocytes in the time NEB and following increase concentration of NEFA and APPs can be some form of meta-inflammation (low - level systemic inflammation, being linked with the metabolic system). It is clear that this finding should stimulate researchers in veterinary medicine to improve their knowledge about the high incidence of the variety of diseases and shorter longevity in dairy cows (Kováč et al. 2016).

In conclusion, our results indicate that higher BCS loss is associated with increased secretion of $\mathrm{Hp}$ and SAA, which can be associated with increased risk of disease development. According to the aforementioned authors, acute phase protein testing is a useful tool for the assessment of health in general, the pathogenesis of various diseases in animals, the spread of infection or the efficacy of treatment. The study demonstrates that decreased BCS may be related to alterations in protein metabolism. Our results suggest negative correlations between $\mathrm{Hp}$, SAA and BCS and report on the dynamics of BCS during the periparturient period in dairy cows. These data contribute to a better understanding of the complicated metabolic changes occurring in dairy cows before and after calving.

\section{Acknowledgement}

This work was supported by the VEGA Scientific Grant No.1/0203/15 from the Ministry of Education, Science, Research and Sport of the Slovak Republic.

\section{References}

Alsemgeest SPM, Taverne MAM, Boosman R, Van Der Weyden B, Gruys E 1993: Peripartum acute-phase protein serum amyloid-A concentration in plasma of cows and fetuses. Am J Vet Res 54: 164-167

Contreras GA, Sordillo LM 2011: Lipid mobilization and inflammatory responses during the transition period of dairy cows. Comp Immunol Microbiol Infect Dis 34: 281-289

Cray C, Zaias J, Altman NH 2009: Acute phase response in animals: a review. Comp Med 59: 517-526

Eckersall PD, Bell R 2010: Acute phase proteins: Biomarkers of infection and inflammation in veterinary medicine. Vet J 185: 23-27

Edmonson AJ, Lean IJ, Weaver LD, Farver T, Webster G 1989: A body condition scoring. Chart for Holstein Dairy Cows. J Dairy Sci 72: 68-78

Gabay C, Kushner I 1999: Acute-phase proteins and other systemic responses to inflammation. N Engl J Med 340: $448-454$

Gymnich S, Hiss S, Sauerwein H, Petersen B 2003: Haptoglobin in sows at parturition. In: Proceedings of the Fourth European Colloquium on Acute Phase Proteins, Segovia, Spain, 136 p.

Chan JPW, Chang CC, Hsu WI, Liu WB, Chen TH 2010: Association of increased serum acute-phase protein concentrations with reproductive performance in dairy cows with postpartum metritis. Vet Clin Path 39: 72-78

Kelton DF, Lissemore KD, Martin RE 1998: Recommendations for recording and calculating the incidence of selected clinical diseases of dairy cattle. J Dairy Sci 81: 2502-2509

Kokkonen T, Taponen J, Anttila T, Syrjälä-Qvist L, Delavaud C, Chilliard Y, Tuori M, Tesfa AT 2005: Effect of body fatness and glucogenic supplement on lipid and protein mobilization and plasma leptin in dairy cows. J Dairy Sci 88: 1127-1141

Kováč G et al. 2001: Diseases of cattle. (In Slovak) M\&M, Prešov, 874 p.

Kováč G, Popelková M, Tkačiková L, Burdová O, Ihnát O 2007: Interrelationship between somatic cell count and acute phase proteins in serum and milk of dairy cows. Acta Vet Brno 76: 51-57

Kováč G, Tóthová C, Nagy O, Seidel H, Konvičná J 2009: Acute phase proteins relation to energy metabolites in dairy cows during the pre- and postpartal period. Acta Vet Brno 78: 441-447

Kováč G, Tóthová CS, Nagy O, Seidel H 2011: Milk amyloid A and selected serum proteins in cows suffering from mastitis. Acta Vet Brno 80: 29-35

Kováč G, Vargová M, Kadaši M, Petrovič V, Tóthová CS 2016: Peripartal health disorders in dairy cows and their solutions. Proceedings from XXIV Szkola Zimowa Hodowcóv Bydla: Produkcja mleka i wolowiny Terazniejszošč i przyszlošč. Zakopane, 7-10.03. 2016, pp 135- 148

Leroy JLMR, Vanholder T, Van Knegsel ATM, Garcia-Ispierto I, Bols PEJ 2008: Nutrient prioritization in dairy cows early postpartum: Mismatch between metabolism and fertility? Reprod Domest Anim 43 (Suppl.): 96-103

Manimaran A, Kumaresan A, Jevakumar S, Mohanty TK, Sejian V, Kumar N, Sreela L, Prakash MA, Mooventhan P, Anantharaj A, Das DN 2016: Potential of acute phase proteins as predictore of postpartum uterine infections during transition period and its reguilatory mechanism in dairy cattle. Vet World 9: 91-100

Markusfeld O, Galon N, Ezra, E 1997: Body condition score, health, yield and fertility in dairy cows. Vet Rec 141: $67-72$ 
Montagner P, Schwegler E, Weschenfelder MM, Krause AR, Alvarado J, Maffi AS, Brauner CC, Shneider A, Schmitt E, Xavier EG, Martins CF, Rabassa VR, Del Pino FAB, Correa MN 2013: Prepartum body condition score changes and the secretion of acute phase proteins in dairy cows. J Dairy Sci 96 (E- Suppl. 1): 591

Mulligan FJ, O'Grady L, Rice DA, Doherty ML 2006: A herd health approach to dairy cow nutrition and production diseases of the transition cow. Anim Reprod Sci 96: 331-353

Murata H, Shimada N, Yoshioka M 2004: Current research on acute phase proteins in veterinary diagnosis: an overview. Vet J 168: $28-40$

Petersen HH, Nielsen JP 2003: Health status and clinical signs in relation to C-reactive protein concentrations in porcine serum. $4^{\text {th }}$ European Colloquium on Acute Phase Proteins, Segovia, Spain, Colloquium, pp 118-119

Pyörälä S 2000: Hirvonen's thesis on acute phase response in dairy cattle. University of Helsinki, Helsinki, Finnland

Sachin J, Vidhi G, and Sania N 2011: Acute-phase proteins: As diagnostic tool. J Pharm Bioallied Sci 3: 118-127

Sheldon IM, Lewis GS, LeBlanc S, Gilbert RO 2006: Defining postpartum uterine disease in cattle. Theriogenology 65: $1516-1530$

Staufenbiel R 1997: Konditionsbeurteilung von Milchkühen mit Hilfe der sonographischen Ruckenfettdickenmessung. Prakt Tierarzt 27: 87-92

Strapák P, Juhás P, Strapáková E, Bujko J, Žitný J, Čanji V 2004: Evaluation of body condition scoring of Slovak Spotted cattle. Acta fytotechnica et zootechnica 3: 72-77

Uchida E, Katoh N, Takahashi K 1993: Appearance of haptoglobin in serum from cows at parturition. J Vet Med Sci 55: 893-894

Vargová M, Petrovič V, Konvičná J, Kadaši M, Záleha P, Kováč G 2015: Hormonal profile and body condition scoring in dairy cows during prepartum and post partum periods. Acta Vet Brno 84: 141-151 